\title{
Economic Aspect of Dairy Farm-Keeping in Jaunpur District of Uttar Pradesh, India
}

\author{
Avanish Kumar Singh* \\ Department of Agricultural Economics, Tilak Dhari P.G. College, \\ Jaunpur-222002 (UP), India \\ *Corresponding author
}

\section{A B S T R A C T}

\section{Keywords}

Dairy farm, Net income, Milk production, Live stock and Cost benefit ratio

Article Info

Accepted:

17 March 2019

Available Online:

10 April 2019
The present investigation is an attempt to study in the title "Economic aspect of dairy farm-keeping in jaunpur district of Uttar Pradesh" specifically, it aims (i) to work out the economics of milk production in different size of dairy units. (ii) to work out the net income and as cost/liter of a dairy farms. (iii) to identify the various constraints in milk production and to suggest measures for promoting live stock development. The study is based on data collected from 16 progressive dairy units in semi-urban areas of Jaunpur district of Uttar Pradesh. The analysis of dairy units revealed that the average cost of milk production is Rs 17.20/liter. The gross returns were found to be highest in cost of large size group as compared to small and marginal groups. The net return after meeting out the cost of production was follow to be highest in large size of dairy units follow by medium and small. The benefit-cost ratios have amply demonstrated profitability of raising dairy farm-keeping on all the size of dairy units. The cost-benefit ratio (BCR) was highest in small size groups. Dairy farmer in different size groups are getting profit from dairy farm.

\section{Introduction}

India ranks first in milk production, according 18.5 percent of world production, achieving an annual output of 146.3 million tons during 2014-15 as compared to 137.69 million tons during 2013-14 recording a growth of 6.26 percent.

The per capita availability of milk in India has increased from 176 gms per day in 1990-91 to 322 gms per day by $2014-15$. It is more than the world average of 294 grams per day during 2013 (Economic Survey 2015-2016). In India state of Utter Pradesh milk Producing state and hold a share of more than $17 \%$ in the total milk production in India. Apart from being the largest milk producer. Uttar Pradesh also has the largest number of Cows \& Buffaloes, which is more than 1.8 crore.

Dairy is a business enterprises established for the harvesting or processing of milk (or both) of animals milk, mostly from cow and buffaloes for human consumption. These animals are source of milk income, 
employment \& poverty relief. The present study has been undertaken with the fallowing objectives-

1.To work out the economics of milk production in different size of dairy units.

2.To estimate the net return and as cost of production per litre in size groups of dairy farms.

3.To identity the various constraints in milk production and suggest measures for promoting live stock development.

\section{Materials and Methods}

The present study was undertaken in Jaunpur district of Uttar Pradesh. It is based on data collected from 16 sample progressive dairy farms of different categories. In semi-urban areas of jaunpur district during the year 20152016.

The dairy farmer keeping form owners are dairy farm. The primary data were collected from the sample of 16 progressive dairy farm selected from 4 blocks (purposively selected on the basis of maximum number of dairy farms in these blocks), on a pre-tested schedule through personal interview method. The number of animals was the basis for formation of strata's i.e. small (minimum 14), marginal (16-25) and large size (above 25) form each size groups 6,8 and 2 dairy units were randomly selected.

The data collected include information regarding total cost of production i.e. expenditure in covered of feed \& fodder, animal care, cattle shade, labor expenses, price of fodder, concentrate \& roughens, milk yield per year per day, price of milk, number of mulch animals, net income etc. under difference size of dairy units. The data were analyzed using statistical tools like average, percentage, ratio and mean etc.

\section{Results and Discussion}

\section{Animal possession according to size of dairy units}

The finding obtained from the present study are presented in Table 1 reveals that the maximum number of cow were found in maximum size groups (20) followed by small (16) and large size groups (12) respectively. Numbers of calves (cow) were also found maximum in medium (10) with 07 and 06 calves in small and medium size groups respectively. Average number of buffaloes and its calves per dairy units were found 26.99, 30.15 and 42.86 percent for small medium and large size groups respectively. It indicates that average number of buffaloes and its calves are more in each size group than the cow and calves.

Thus, it could be calculated that the average number of livestock (both cow and buffaloes) increase with increase in size groups.

\section{Operational and fixed cost for milk production}

Table 2 reveals that the total cost per animal per year was highest in medium size groups fallowed by small and large size groups followed by small and large size groups. It was Rs 86858.29, 96705.10 and Rs 90054.45 for small and large size groups respectively. It was observed that the maximum portion (96.93 percent) of total cost was covered by operational cost in all size groups. The operational cost increases as the size group's increase. As for as fixed cost is concerned, it decreases as the size groups increases. Under operational cost in different size groups. The feed cost per animal per day was observed maximum and minimum, i.e., 80.11 and 63.04 for medium and small size group respectively. Total cost per animal per day was also found to be of the same trend as that of total cost per 
animal per year. Therefore, it can be concluded that the total cost of animal milk production was observed highest in medium size groups followed by large and small size groups. The much portion of total cost is covered by operation cost in all the size groups. On an average, the feed costs per year per day were observed to be Rs 72.350and total cost per year per day Rs 294087 in all size groups.

\section{Net income from different size of dairy units}

The returns were computed using prevailing marked prices of output and input. The details of which is presented in Table 3. It could be observed that the gross income per year increases as size group increases. It was Rs 12646.00, Rs 131939.43 and Rs 133458.37 for small, medium and large size groups respectively. The gross expenses have been observed in medium size groups. It was Rs 59910.02, Rs 59029.16 and 55074.02 for medium, large and small groups respectively. The net income per animal per year was observed in small, medium and large size groups. It was Rs 71390.98 , Rs 72389.43 and Rs 74789.23 for small, medium and large respectively. On an average the cost of production per liter of milk was observed to be Rs 14.21 for all size groups respectively. The benefit -cost ratio (BCR) for per animal was highest in small size groups followed by large and medium size groups. It was Rs 2:30, 2:26 and 2:20 for small, large and medium size groups respectively. Thus, it can be concluded that the respectively in different size groups are getting profit from dairy enterprises in the study area.

\section{Problem faced by farmer}

Farmer or grower are faced main problem of the supply of milk is of inadequate feed and over stocking the grazing land.
Marking channel is also insufficient.

Poor road and inadequate transport facility due to which marketing cost is high. Cattle raising are a high risk business. Prevention of cattle disease is inadequate and replacement is a costly.

\section{Suggestions}

\section{Promoting livestock development}

The need for live-stock development production is pressing giving the rapidly growing demand from animal product and important contribution of live stock to the incomes and welfare of rural poor.

The following measures are suggested for the development of dairy farm keeping.

More research is needed on improved animal husbandry and production system.

Area under folder crop and production of grazing land should be increased.

Fixation of minimum milk price, and promote extension services, health care and marketing facilities for milk production.

Summary and conclusion are as follows:

The present investigation is an attempt to study in the title "Economic aspect of dairy farm-keeping in jaunpur district of Uttar Pradesh" specifically, it aims (i) to work out the economics of milk production in different size of dairy units. (ii) to work out the net income and as cost/liter of a dairy farms. (iii) to identify the various constraints in milk production and to suggest measures for promoting live stock development. The study is based on data collected from 16 progressive dairy units in semi- urban areas of Jaunpur district of Uttar Pradesh during the year 201516. The analysis of dairy units revealed that the average cost of milk production is Rs 17.21/liter. 
Table.1 Animal possession in different size of dairy units

(in Numbers)

\begin{tabular}{|c|c|c|c|c|c|c|c|c|}
\hline Size Group & Dairy Unit & Cow & Calves /Heifers & Sub Total & Buffaloes & Calves/Heifers & Sub Total & Totals \\
\hline Small & 06 & 16 & 07 & 23 & 24 & 10 & 34 & 57 \\
& & $(33.33)$ & $(30.43)$ & $(32.40)$ & $(24.49)$ & $(35.71)$ & $(26.99)$ & $(28.93)$ \\
\hline Medium & 08 & 20 & 10 & 30 & 32 & 06 & 38 & 68 \\
& & $(41.67)$ & $(43.47)$ & $(42.25)$ & $(32.65)$ & $(21.43)$ & $(30.15)$ & $(34.52)$ \\
\hline Large & 02 & 12 & 06 & 18 & 42 & 12 & 54 & 72 \\
& & $(25.00)$ & $(26.09)$ & $(25.35)$ & $(42.86)$ & $(42.86)$ & $(42.86)$ & $(36.55)$ \\
\hline Total & 16 & 48 & 23 & 71 & 48 & 28 & 126 & 197 \\
& & $(100)$ & $(100)$ & $(100)$ & $(100)$ & $(100)$ & $(100)$ & $(100)$ \\
\hline
\end{tabular}

Table.2 Operational and fixed cost for milk production

(in Rupees)

\begin{tabular}{|c|c|c|c|c|c|c|c|c|}
\hline \multirow[t]{3}{*}{ Cost Items } & \multicolumn{6}{|c|}{ Size Group } & \multirow{2}{*}{\multicolumn{2}{|c|}{ Average of all size group }} \\
\hline & \multicolumn{2}{|l|}{ Small } & \multicolumn{2}{|l|}{ Medium } & \multicolumn{2}{|l|}{ Large } & & \\
\hline & $\begin{array}{c}\text { Per } \\
\text { Animal/year }\end{array}$ & $\begin{array}{c}\text { Per } \\
\text { Animal/Day }\end{array}$ & $\begin{array}{c}\text { Per } \\
\text { Animal/year }\end{array}$ & $\begin{array}{c}\text { Per } \\
\text { Animal/Day }\end{array}$ & $\begin{array}{c}\text { Per } \\
\text { Animal/year }\end{array}$ & $\begin{array}{c}\text { Per } \\
\text { Animal/Day }\end{array}$ & $\begin{array}{c}\text { Per } \\
\text { Animal/year }\end{array}$ & $\begin{array}{c}\text { Per } \\
\text { Animal/Day }\end{array}$ \\
\hline $\begin{array}{l}\text { Operational } \\
\text { cost }\end{array}$ & $\begin{array}{c}40759.55 \\
(46.93)\end{array}$ & 111.67 & $\begin{array}{c}45791.73 \\
(43.35)\end{array}$ & 25.45 & $\begin{array}{c}43077.55 \\
(43.84)\end{array}$ & 118.02 & $\begin{array}{c}43209.61 \\
(47.38)\end{array}$ & 118.38 \\
\hline $\begin{array}{l}\text { Fixed } \\
\text { expenses }\end{array}$ & $\begin{array}{c}23010 \\
(26.50)\end{array}$ & 63.04 & $\begin{array}{c}29243.43 \\
(30.24)\end{array}$ & 80.11 & $\begin{array}{c}26978.09 \\
(29.96)\end{array}$ & 73.91 & $\begin{array}{c}26410.67 \\
(28.96)\end{array}$ & 72.35 \\
\hline $\begin{array}{l}\text { Labour } \\
\text { expenses }\end{array}$ & $\begin{array}{c}4200.00 \\
(4.84)\end{array}$ & 11.50 & $\begin{array}{c}3392.65 \\
(3.51)\end{array}$ & 9.29 & $\begin{array}{c}3055.94 \\
(3.39)\end{array}$ & 8.37 & $\begin{array}{c}3549.53 \\
(3.90)\end{array}$ & 9.72 \\
\hline $\begin{array}{l}\text { Interest on } \\
\text { work in } \\
\text { capital }\end{array}$ & $\begin{array}{c}2088.00 \\
(2.40)\end{array}$ & 5.72 & $\begin{array}{c}2504.35 \\
(2.59)\end{array}$ & 6.86 & $\begin{array}{c}2170.17 \\
(2.41)\end{array}$ & 5.94 & $\begin{array}{c}2254.17 \\
(2.47)\end{array}$ & 6.17 \\
\hline Fixed cost & $\begin{array}{c}8400.12 \\
(9.67)\end{array}$ & 23.01 & $\begin{array}{c}7886.47 \\
(8.16)\end{array}$ & 21.60 & $\begin{array}{c}7386.35 \\
(8.20)\end{array}$ & 20.23 & $\begin{array}{c}7890.98 \\
(8.65)\end{array}$ & 21.61 \\
\hline $\begin{array}{l}\text { Depreciation } \\
\text { on fixed } \\
\text { capital }\end{array}$ & $\begin{array}{c}3594.60 \\
(4.13)\end{array}$ & 9.84 & $\begin{array}{c}3380.95 \\
(3.50)\end{array}$ & 9.26 & $\begin{array}{c}3180.95 \\
(3.53)\end{array}$ & 8.71 & $\begin{array}{c}3385.50 \\
(3.71)\end{array}$ & 9.27 \\
\hline $\begin{array}{l}\text { Interest on } \\
\text { fixed capital }\end{array}$ & $\begin{array}{c}4805.52 \\
(5.33)\end{array}$ & 13.16 & $\begin{array}{c}4505.52 \\
(4.66)\end{array}$ & 12.34 & $\begin{array}{c}4205.40 \\
(6.67)\end{array}$ & 11.52 & $\begin{array}{c}4505.48 \\
(4.94)\end{array}$ & 12.34 \\
\hline Total & $\begin{array}{c}86858.29 \\
(100)\end{array}$ & 237.96 & $\begin{array}{c}96705.10 \\
(100)\end{array}$ & 264.94 & $\begin{array}{c}90054.45 \\
(100)\end{array}$ & 246.72 & $\begin{array}{c}91205.94 \\
(100)\end{array}$ & 249.87 \\
\hline
\end{tabular}

Table.3 Net returns from dairy units

\begin{tabular}{|c|c|c|c|c|c|c|c|c|}
\hline \multirow{3}{*}{ Particulars } & \multicolumn{6}{|c|}{ Size Group } & \multirow{2}{*}{\multicolumn{2}{|c|}{ Average of all size group }} \\
\hline & \multicolumn{2}{|c|}{ Small } & \multicolumn{2}{|c|}{ Medium } & \multicolumn{2}{|c|}{ Large } & & \\
\hline & $\begin{array}{c}\text { Per Animal/ } \\
\text { Year }\end{array}$ & $\begin{array}{c}\text { Per } \\
\text { Animal/day }\end{array}$ & $\begin{array}{l}\text { Per Animal/ } \\
\text { year }\end{array}$ & $\begin{array}{c}\text { Per } \\
\text { Animal/day }\end{array}$ & $\begin{array}{l}\text { Per Animal/ } \\
\text { year }\end{array}$ & $\begin{array}{c}\text { Per } \\
\text { Animal/day }\end{array}$ & $\begin{array}{l}\text { Per Animal/ } \\
\text { year }\end{array}$ & $\begin{array}{l}\text { Per Animal/ } \\
\text { day }\end{array}$ \\
\hline Gross Income & 126465 & 346.47 & 131939.43 & 361.47 & 133458.37 & 365.63 & 130620.93 & 357.86 \\
\hline Gross expenses & 55074.02 & 150.88 & 59910.02 & 164.13 & 59029.16 & 161.72 & 58004.40 & 158.91 \\
\hline Net Income & 71390.98 & 195.59 & 72389.43 & 198.32 & 74789.23 & 204.90 & 72856.54 & 14.21 \\
\hline Net profit/liter milk & - & 3.07 & - & 2.99 & - & 3.18 & - & 199.60 \\
\hline $\begin{array}{l}\text { Cost of } \\
\text { production/liter }\end{array}$ & - & 14.39 & - & 14.36 & - & 132.88 & - & 3.08 \\
\hline Price of milk Rs/liter & - & 50 & - & 40 & - & 30 & - & 40 \\
\hline Benefit-cost ratio & - & $2: 30$ & - & $2: 20$ & - & $2: 26$ & - & $2: 25$ \\
\hline
\end{tabular}


The gross returns were found to be highest in cost of large size group as compared to small and marginal groups. The net return after meeting out the cost of production was follow to be highest in large size of dairy units follow by medium and small.

The benefit-cost ratios have amply demonstrated profitability of raising dairy farm- keeping on all the size of dairy units. The present study was undertaken in Jaunpur district of Uttar Pradesh in order to throw light on economic aspect of dairy farmkeeping.

The study revealed that the total cost (operational and fixed cost) of milk production increases size groups increases, the net income follow). The major portion of total cost is covered by operational cost in all the size groups. It can be concluded that dairy enterprises is economically viable in Jaunpur district.

\section{References}

Acharya, T.K.T. and Pawar, T.G. (1980). The economics of milk production by different types of milk animal. Indian journal of agricultural economics, 35(4); 153.

Ganesh, B.K., Sharma, S. and Pandean, A. (2003). Study on cost of milk production in the milk shade area of Tamilnadu. Indian Journal of animal science, 73(8); 920-923.

Kunal, L.B., Gaddi. G.M. and Megeri, S.N. (1997). Study on comparative economic analysis of different breeds of cows. Dharwad dist. of Karnataka state. Agriculture Banker, 30(3); 44 -47.

Sarawgi, A.K. and Viaidya, P.K. (2000). Economics of buffalo and cow milk production in Jabalpur dist. of Madhya Pradesh. The Bihar journal of agricultural marketing, vol.VIII. No.4, Oct-Dec.

\section{How to cite this article:}

Avanish Kumar Singh. 2019. Economic Aspect of Dairy Farm-Keeping in Jaunpur District of Uttar Pradesh, India. Int.J.Curr.Microbiol.App.Sci. 8(04): 2574-2578. doi: https://doi.org/10.20546/ijcmas.2019.804.299 